\title{
Setting conservation priorities for the Moroccan herpetofauna: the utility of regional red lists
}

\author{
Juan M. Pleguezuelos, José C. Brito, Soumía Fahd, Mónica Feriche \\ José A. Mateo, Gregorio Moreno-Rueda, Ricardo Reques and Xavier Santos
}

\begin{abstract}
We assess the national conservation status of the amphibians and reptiles of Morocco by applying the IUCN Red List Criteria at the national level and assess its utility as a planning tool to establish regional priorities for conservation. We rely on the accessory data accompanying regional red lists, mainly distribution range and habitats used by, and threats affecting, species of conservation concern. We also correlated some natural history traits to examine the nature and causes of the risk of extinction. With 13 species of amphibians (31\% regionally threatened) and 99 species of reptiles (14\% regionally threatened), Morocco is one of the Mediterranean countries with the highest diversity of herpetofauna, mainly because of the high percentage of endemism (amphibians 31\%, reptiles $24 \%$ ). The relative frequencies of threatened species were found to be contingent on both taxonomic group and habitat. The overwhelming importance of the threats of small range and number of habitats used by species is different from the threats to the same species at the global level; this demonstrates the usefulness of national or regional analyses of conservation status for setting conservation priorities. The importance of regional assessment derives from the fact that the boundaries set for conservation management are mainly political rather than biogeographical.
\end{abstract}

Keywords Amphibians, conservation, crocodiles, Morocco, herpetofauna, Red List, regional red lists, reptiles

This paper contains supplementary material that can be found online at http://journals.cambridge.org

Juan M. Pleguezuelos (Corresponding author), Mónica Feriche and Gregorio Moreno-RuedA* Departamento de Biología Animal, Facultad de Ciencias, Universidad de Granada, E-18071 Granada, Spain. E-mail juanple@ugr.es

José C. BRITo CIBIO, Instituto de Ciências Agrárias Vairao, Vairao, Portugal

Soumía Fahd Département de Biologie, Faculté des Sciences, Université Abdelmalek Essaddi, Tetuan, Morocco

José A. Mateo Lagartario La Gomera, Valle Gran Rey-La Gomera (S/C Tenerife), Spain

Ricardo Reques Estación Biológica de Doñana, CSIC, Seville, Spain

Xavier Santos Departament de Biologia Animal, Universitat de Barcelona, Spain

*Also at: KLIVV, Österreischische Academie der Wissenschaften, Vienna, Austria

Received 15 May 2009. Revision requested 16 June 2009.

Accepted 26 June 2009.

\section{Introduction}

The conservation status of species is one of the most 1 widely used indicators for assessing an ecosystem's wealth (Butchart et al., 2006), and the IUCN Red List of Threatened Species (IUCN, 2010b) is widely recognized as the most comprehensive way to evaluate conservation status (Rodrigues et al., 2006; Miller et al., 2007). The Red List, although with several limitations (Possingham et al., 2002), has become an increasingly powerful tool in setting priorities for the allocation of effort and funds for biodiversity conservation (Trousdale \& Gregory, 2004). In addition, the Red List Criteria (IUCN, 2008), although designed to be applied at a global scale, have inspired several authorities to apply the procedure nationally (Pinchera \& Boitani, 1997; Eaton et al., 2005). Assessment for national red lists could be useful because it provides the global Red List with valuable local information (Gärdenfors et al., 2001), it is vital to conservation globally (Rodríguez et al., 2000), and the use of standardized criteria, adapted from the IUCN Red List Criteria, offers the possibility of universally comparable assessments (Miller et al., 2007). Despite the interest in constructing regional red lists, however, there has been limited testing of this application (Gärdenfors, 2001) or of the comparison between lists at the national and global levels (but see Milner-Gulland et al., 2006). Because of lack of staff or funds assessment of the national conservation status of plants and animals has failed, particularly in developing countries (Ascher \& Healy, 1990). However, some of these countries harbour the most important biodiversity hotspots (Myers et al., 2000) and, because of socio-economic constraints, have many threatened species (Hoffmann, 2004).

The conservation status of the amphibians and reptiles of the Mediterranean Basin has been assessed at the global level (Cox et al., 2006) but the herpetofauna of Morocco exhibit some characteristics that merit particular attention. Compared to other Mediterranean countries Morocco has a high diversity of terrestrial reptile species, the highest percentage of endemic reptile species, and the highest number of European relict reptile species. Morocco also harbours centres of diversity of some reptile genera (Acanthodactylus, Chalcides and Blanus).

The primary function of the IUCN Red List is to assess the extinction risk of species globally (IUCN, 2008). The data presented in the Red List include information collected to support the assessments (distribution and habitats of, and threats to, the taxa assessed), and this information 
provides a baseline for setting conservation priorities (Rodrigues et al., 2006). Using this information for summarizing biological characteristics of species at risk, key habitats for conservation, and more generalized threats, would address one of the shortfalls of the IUCN Red List, which is its lack of suitability for setting recovery actions for the greatest number of species and habitats (Noss, 2000). Analyses within the geopolitical limits of a country are useful (Czech \& Krausman, 1997) because most conservation decisions and budgets are planned independently by country (Rodrigues \& Gaston, 2002; Samways, 2003).

We explored the data gathered during the process of performing a national red list of the amphibians and reptiles of Morocco to determine (1) the extinction risk of Moroccan amphibians and reptiles at the national level, and to identify (2) the groups facing the highest extinction risk, (3) the habitats that hold the most threatened species, (4) the most significant threats, and (5) the relationships between the threatened status of species and their natural history. We also sought to establish whether threatened Moroccan species share some of the traits reported to predict species vulnerability (Webb et al., 2002). This analysis will assist conservation planning in Morocco and provide information about two groups of terrestrial vertebrates frequently neglected in conservation policy and consistently underrepresented in networks of protected areas (MilnerGulland et al., 2006).

\section{Methods}

We assessed the conservation status of the 13 amphibian species and 101 reptile species (99 extant plus two Regionally Extinct) known to occur in Morocco (Western Sahara included; total area $710,850 \mathrm{~km}^{2}$ ). The initial species list was compiled from two distribution atlases that cover the area entirely (Bons \& Geniez, 1996) or partially (Geniez et al., 2004), although we considered recent changes in taxonomy (Appendix 1). The complete list of species is presented in Appendix 2. Reptiles, a paraphyletic group, is considered here in its traditional sense. To evaluate extinction risk we used the Red List Criteria (IUCN, 2008) and followed the guidelines for its application at the regional level (IUCN, 2003). These guidelines are established (Gärdenfors, 2001; Gärdenfors et al., 2001; Miller et al., 2007) and rely on three premises: (1) if the taxon is endemic to the region or if the regional population of a species to be assessed is isolated from conspecific populations outside the region, the criteria must be used without modification; (2) if the population within the region could undergo a 'rescue effect' from populations outside the region, the resulting category must be downgraded; (3) if the population within the region is a demographic sink and the extra-regional source is expected to decrease or cannot perform a rescue effect, the extinction risk of the regional population may be upgraded. In Appendix
2 we followed the Habitats Authority File and the Threats Type Authority File of the IUCN (IUCN, 2010a). A species is considered Threatened when it appeared listed in one of the IUCN categories of Vulnerable, Endangered or Critically Endangered, according to the criteria of Population Reduction (A), Geographic Range (B), Small Population Size and Decline (C) and Very Small or Restricted Population (D; IUCN, 2008).

For a regional assessment it is important to consider the proportion of the global distribution that occurs within the region (IUCN, 2003), and this was estimated for Morocco from Cox et al. (2006) using the geographical information system ArcView v. 3.2 (ESRI, Redlands, USA; Appendix 2). We relied where possible on published information but also on our experience researching amphibians and reptiles in Morocco during the past 2 decades (Pearman, 2001). The distribution of the main habitats in Morocco was obtained from 14 months (1999-2000) of 1-km resolution data acquired by the VEGETATION sensor of the SPOT 4 satellite, delivered as multichannel daily mosaics (GLC, 2003).We made statistical comparisons (with $\chi^{2}$ tests) of the frequencies of categories, habitats and threats between Morocco and the Mediterranean Basin only for reptiles because of the small sample size for amphibians. Because of unbalanced sample size, expected frequencies were adjusted to the lesser sample size of the Moroccan fauna. To examine any potential relationship between natural history traits and threatened status we were constrained to those few traits available: (1) distribution breadth, assessed by the number of 1:50,000 Moroccan topographic sheets with a record of presence in Bons \& Geniez (1996), corrected with Geniez et al. (2004); (2) number of IUCN minor habitats (the second level for habitat type in the Habitats Authority File of the IUCN; see Appendix 2); (3) body size, measured as the average snout-vent length for adults of the largest sex; (4) reproductive output, measured as mean annual number of eggs or newborn.

We compared natural history traits between threatened and non-threatened species with a Mann-Whitney U-test. To test for an association between threatened status and these predictor variables we used a generalized linear model (GLM) with a binomial distribution of errors (threatened vs non-threatened) linked to a logit function. To eliminate variables without significant effects we selected the best models using the Akaike information criterion (AIC: Burnham \& Anderson, 2004). As species with common ancestry are not independent, a control for phylogeny is advisable (Pagel \& Harvey, 1988) but the absence of phylogenies for many of the groups considered precluded an analysis by contrasts, and therefore we performed the same analysis with genus and family as statistical units (Pagel \& Harvey, 1988). This procedure would diminish the error because of the non-independence of the statistical units, and similar results across the taxonomic levels would suggest that they were not confounded by phylogeny. 


\section{Results}

Our proposed national red list of the amphibians and reptiles of Morocco indicates that $30.8 \%$ of the 13 amphibian species and $13.9 \%$ of the 101 reptile species are threatened (Table 1, Appendix 2). Two reptile species are Regionally Extinct. Of the reptiles, $25.0 \%$ of the continental chelonians, $12.1 \%$ of the saurians, $18.5 \%$ of the snakes and none of the amphisbaenians are threatened (Table 1). The percentage endemism of Moroccan amphibians and reptiles is 30.7 and $23.8 \%$, respectively. Of the reptile family Scincidae (with 18 species in Morocco) 33.3\% are threatened and $50 \%$ endemic. All threatened species of amphibians were categorized by criteria B (geographic range) of the Red List Criteria, and for reptiles 10 of the 14 threatened species were categorized by criteria $\mathrm{B}$, two by criteria A (reduction in population size) and two by criteria $\mathrm{D}$ (population size or area of occupancy; Appendix 2). Criteria B was used for the evaluation of $78 \%$ of the threatened species.

Comparing threatened species at the Moroccan and global scales, three amphibian species were categorized at higher risk at the regional scale, and none at lower risk, and 12 reptile species were categorized at higher risk, and three at lower risk (Appendix 2). The frequency of threat categories of reptiles differed significantly between the two geographical scales $\left(\chi_{6}^{2}=30.34, \mathrm{P}<0.001\right.$; Table 1$)$.

Amphibians occur in most major habitats in Morocco, and threatened species are notably present in savannah and desert habitats (Table 2). Reptiles occur in all major habitats, and there is no difference in occurrence between threatened and non-threatened species $\left(\chi_{9}^{2}=2.51, \mathrm{P}=0.98\right.$;
Table 2). There is no correlation between the number of non-threatened and threatened species and habitat area $\left(r_{\mathrm{s}}<0.22\right.$ for both comparisons). The habitats in which threatened reptiles most frequently occur are scrublands and grasslands (Table 2). Threatened amphibians occur on average in fewer minor habitat types (mean $=5.0 \pm \mathrm{SD} 2.9$, $\mathrm{n}=4$ ) than non-threatened species (mean $=13.1 \pm \mathrm{SD} 5.7$, $\mathrm{n}=9$; U-test, $Z=2.08, \mathrm{P}<0.05)$, and the same is true for reptiles (mean $=3.2 \pm \mathrm{SD} 1.8, \mathrm{n}=14$ vs mean $=5.3 \pm \mathrm{SD}_{3.2}$, $\mathrm{n}=87$; U-test, $Z=2.44, \mathrm{P}=0.01$; Appendix 2).

The most pervasive threats to amphibians in Morocco are habitat loss and degradation, affecting $100 \%$ of the threatened species and $69 \%$ of all species (Table 3 ). The primary causes of habitat loss are shifts in agricultural practices and groundwater extraction.

The most pervasive threats to Moroccan reptiles are the intrinsic factors of the species, affecting $100 \%$ of the threatened species, followed by habitat loss, accidental mortality and harvesting (hunting/gathering; Table 4). The main intrinsic factors that place reptiles at risk of extinction are restricted range, low density and limited dispersal capacity. The main causes of habitat loss are the increasing surface area devoted to modern agriculture. Harvesting threatens reptile species in Morocco, mostly snakes, because of collection for traditional medicine and entertainment. Different sets of threats affected Moroccan and Mediterranean reptiles considering either all species $\left(\chi_{11}^{2}=148.76, \mathrm{P}<0.001\right)$ or only threatened species $\left(\chi_{10}^{2}=475.02, \mathrm{P}<0.001\right)$. Intrinsic factors have more impact on Moroccan than on Mediterranean reptiles, and Moroccan reptiles are less affected by habitat

TABLE 1 Summary of our national red list assessment of the amphibians and reptiles of Morocco, and the number of endemic species in each group, with a summary of the global status of the amphibians and reptiles of the Mediterranean Basin (from Cox et al., 2006) and, for reptiles only, $\chi^{2}$ tests between the total numbers in each category in Morocco and the Mediterranean Basin.

\begin{tabular}{|c|c|c|c|c|c|c|c|c|c|}
\hline & \multicolumn{7}{|c|}{ Red list status $^{1}$} & \multirow[b]{2}{*}{ Total } & \multirow{2}{*}{$\begin{array}{l}\text { No. of endemic } \\
\text { species }\end{array}$} \\
\hline & $\mathrm{RE}(\mathrm{EX})$ & CR & EN & VU & NT & $\mathrm{DD}$ & $\mathrm{LC}$ & & \\
\hline \multicolumn{10}{|l|}{ Morocco } \\
\hline Anura & & & 1 & 2 & 3 & & 5 & 11 & 4 \\
\hline Urodela & & & & 1 & 1 & & & 2 & 0 \\
\hline Amphibia total & & & 1 & 3 & 4 & & 5 & 13 & 4 \\
\hline Testudines & 1 & & & 1 & & & 2 & 4 & 0 \\
\hline Amphisbaenia & & & & & & & 3 & 3 & 2 \\
\hline Sauria & & 1 & 4 & 3 & 12 & & 46 & 66 & 21 \\
\hline Ophidia & & & & 5 & 5 & 3 & 14 & 27 & 1 \\
\hline Crocodylia & 1 & & & & & & & 1 & 0 \\
\hline Reptilia total & 2 & 1 & 4 & 9 & 17 & 3 & 65 & 101 & 24 \\
\hline \multicolumn{10}{|c|}{ Mediterranean Basin } \\
\hline Amphibia & 1 & 1 & 13 & 13 & 17 & & 61 & 106 & \\
\hline Reptilia & 1 & 13 & 22 & 11 & 36 & 19 & 253 & 355 & \\
\hline \multicolumn{10}{|c|}{$\chi^{2}$ (Reptilia: Morocco vs Mediterranean) } \\
\hline & 3.4 & 1.8 & 0.6 & $5.6^{* *}$ & 2.6 & 0.9 & 0.3 & & \\
\hline
\end{tabular}

${ }^{1}$ RE, Regionally Extinct; EX, Extinct; CR, Critically Endangered; EN, Endangered; VU, Vulnerable; NT, Near Threatened; DD, Data Deficient; LC, Least Concern; ${ }^{* *}, \mathrm{P}<0.01$ 
TABLE 2 The numbers of threatened and non-threatened species of amphibians and reptiles (with column-wise percentages in parentheses) that occur in each habitat type in Morocco (considering only major habitats from the Habitat Authority File of the IUCN, 2010b), $\chi^{2}$ tests between the numbers of threatened and non-threatened reptile species that occur in these habitats in Morocco (all differences are non-significant), and the area of these major habitats in Morocco, taken from the Global Land Cover 2000 Project (GLCP; see Methods). As the GLCP did not identify exactly the same habitats as the Habitat Authority File the following pairs of major habitats in the Habitat Authority File were combined for the calculation of area: grassland + savannah, desert + coastline, wetlands + artificial aquatic.

\begin{tabular}{|c|c|c|c|c|c|c|}
\hline & \multicolumn{2}{|l|}{ Amphibians } & \multicolumn{3}{|l|}{ Reptiles } & \multirow[b]{2}{*}{ Area, $\mathrm{km}^{2}(\%)$} \\
\hline & Threatened (\%) & Non-threatened (\%) & Threatened (\%) & Non-threatened (\%) & $\chi^{2}$ & \\
\hline Forest & $1(8.3)$ & $5(11.9)$ & $2(5.7)$ & $22(7.4)$ & 0.13 & $18,257(2.4)$ \\
\hline Scrubland & $2(16.7)$ & $6(14.3)$ & $9(25.7)$ & $56(18.8)$ & 0.89 & $36,740(5.2)$ \\
\hline Savannah & $2(16.7)$ & $1(2.4)$ & $2(5.7)$ & $21(7.0)$ & 0.08 & $149,161(21.0)$ \\
\hline Grassland & $1(8.3)$ & $6(14.3)$ & $7(20.0)$ & $62(20.8)$ & 0.01 & \\
\hline Rocky & & & $3(8.6)$ & $28(9.4)$ & 0.02 & $142,462(20.1)$ \\
\hline Desert & $2(16.7)$ & $1(2.4)$ & $4(11.4)$ & $39(13.1)$ & 0.07 & $267,855(36.5)$ \\
\hline Coastline & & & $2(5.7)$ & $23(7.7)$ & 0.18 & \\
\hline Artificial terrestrial & $1(8.3)$ & $6(14.3)$ & $5(14.3)$ & $39(13.1)$ & 0.03 & $93,081(0.4)$ \\
\hline Wetland & $2(16.7)$ & $9(21.4)$ & $1(2.8)$ & $4(1.3)$ & 0.59 & $852(0.1)$ \\
\hline Artificial aquatic & $1(8.3)$ & $8(19.0)$ & $0(0.0)$ & $4(1.3)$ & 0.46 & \\
\hline
\end{tabular}

loss, invasive species, human disturbance and pollution (Table 4).

Threatened reptile species have, on average, a more restricted distribution (presence in $9.7 \pm \mathrm{SD} 11.1$ topographic sheets; $\mathrm{n}=14)$ than non-threatened species $(58.0 \pm$ SD 55.2, $\mathrm{n}=85 ; Z=4.3, \mathrm{P}<0.001)$ and use fewer minor habitats. There is no difference in body size $(317.1 \pm$ SD $325.6 \mathrm{~mm}$ snout-vent length vs $224.9 \pm$ SD $276.4 \mathrm{~mm}$ snout-vent length; $Z=1.39, \mathrm{P}=0.2)$ or reproductive output $(8.4 \pm \mathrm{SD}$ 6.6 eggs or newborn vs $8.3 \pm$ SD 5.8 eggs or newborn; $Z=0.03, \mathrm{P}=0.97$ ) between threatened and non-threatened species. In the GLMs distribution range was not included as a predictor variable because it was frequently used as a criterion to evaluate the conservation status and its inclusion would therefore be tautological. Four models were statistically significant, all of them including the number of habitats. The best model included number of habitats and body size but the effect of body size was not significant (Wald statistic $=2.78, \mathrm{P}=0.10$ ). The second best model only included the number of habitats but the AIC value increased only marginally (Table 5). The same results were obtained at the genus and family levels (the latter was nonsignificant, probably because of small sample size; Table 5). These results suggest that the number of habitats in which a species occurs is an important predictor of the conservation status of reptiles.

\section{Discussion}

The number of amphibian species in Morocco is low but similar to other African countries north of the Sahara (Schleich et al., 1996). However, the species richness of Moroccan reptiles is one of the highest amongst the countries of the Mediterranean Basin and similar to that

TABLE 3 Number of threatened and non-threatened amphibian species in Morocco (this study) and the Mediterranean Basin (global Red List assessment, from Cox et al., 2006) affected by major threats (from the Threats Type Authority File of the IUCN; IUCN, 2010b). Note that species assessed overall as not falling into one of the IUCN threat categories may still, nevertheless, be subject to some threats.

\begin{tabular}{|c|c|c|c|c|}
\hline \multirow[b]{2}{*}{ Threat } & \multicolumn{2}{|l|}{ Morocco } & \multicolumn{2}{|c|}{ Mediterranean } \\
\hline & Threatened & Non- threatened & Threatened & Non-threatened \\
\hline None & 0 & 4 & 0 & 9 \\
\hline Habitat loss & 4 & 5 & 19 & 67 \\
\hline Invasive species & 1 & 3 & 6 & 32 \\
\hline Harvesting & 0 & 1 & 4 & 11 \\
\hline Accidental mortality & 1 & 3 & 0 & 4 \\
\hline Direct persecution & 0 & 0 & 0 & 0 \\
\hline Pollution & 2 & 5 & 13 & 55 \\
\hline Natural disasters & 3 & 1 & 3 & 16 \\
\hline Change in native species dynamics & 0 & 0 & 1 & 6 \\
\hline Intrinsic factors & 4 & 3 & 16 & 14 \\
\hline Human disturbance & 0 & 0 & 3 & 1 \\
\hline
\end{tabular}


TABLE 4 Number of threatened and non-threatened reptile species in Morocco (this study), with $\chi^{2}$ tests ${ }^{1}$ of differences in frequencies, and the Mediterranean Basin (global Red List assessment, from Cox et al., 2006) affected by major threats (from the Threats Type Authority File of the IUCN; IUCN, 2010b), and $\chi^{2}$ tests $^{1}$ between between Morocco and the Mediterranean Basin for frequencies of all species and threatened species. Species assessed overall as not falling into one of the IUCN threat categories may still, nevertheless, be subject to some threats.

\begin{tabular}{|c|c|c|c|c|c|c|c|}
\hline \multirow[b]{2}{*}{ Threat } & \multicolumn{3}{|l|}{ Morocco } & \multicolumn{2}{|c|}{ Mediterranean } & \multirow{2}{*}{$\begin{array}{l}\chi^{2} \text { (Morocco vs } \\
\text { Mediterranean, } \\
\text { all spp.) }\end{array}$} & \multirow{2}{*}{$\begin{array}{l}\chi^{2} \text { (Morocco vs } \\
\text { Mediterranean, } \\
\text { threatened spp.) }\end{array}$} \\
\hline & Threatened & $\begin{array}{l}\text { Non- } \\
\text { threatened }\end{array}$ & $\chi^{2}$ & Threatened & $\begin{array}{l}\text { Non- } \\
\text { threatened }\end{array}$ & & \\
\hline None & 0 & 39 & & 0 & 76 & $10.46^{* *}$ & $0.00^{\mathrm{ns}}$ \\
\hline Habitat loss & 10 & 19 & $4.26^{*}$ & 38 & 161 & $16.59^{* * *}$ & $2.71^{\mathrm{ns}}$ \\
\hline Invasive species & 0 & 0 & & 8 & 12 & $6.85^{\star *}$ & $3.67^{\mathrm{ns}}$ \\
\hline Harvesting & 4 & 16 & $9.00^{* *}$ & 14 & 67 & $0.76^{\mathrm{ns}}$ & $0.74^{\mathrm{ns}}$ \\
\hline Accidental mortality & 4 & 20 & $12.80^{* *}$ & 7 & 34 & $11.56^{* * *}$ & $3.43^{\text {ns }}$ \\
\hline Direct persecution & 5 & 16 & $7.56^{* *}$ & 4 & 53 & $0.29^{\text {ns }}$ & $6.95^{\star *}$ \\
\hline Pollution & 1 & 1 & $0.00^{\mathrm{ns}}$ & 7 & 26 & $7.87^{\star *}$ & $1.57^{\mathrm{ns}}$ \\
\hline Natural disasters & 1 & 2 & $0.50^{\mathrm{ns}}$ & 3 & 3 & $0.31^{\mathrm{ns}}$ & $0.25^{\mathrm{ns}}$ \\
\hline Change in native species dynamics & 0 & 0 & & 4 & 7 & $0.00^{\mathrm{ns}}$ & $0.00^{\mathrm{ns}}$ \\
\hline Intrinsic factors & 14 & 25 & $4.84^{\star}$ & 22 & 14 & $89.15^{\star * *}$ & $452.61^{* * *}$ \\
\hline Human disturbance & 1 & 3 & $1.33^{\mathrm{ns}}$ & 10 & 23 & $4.91^{\star}$ & $3.10^{\mathrm{ns}}$ \\
\hline
\end{tabular}

${ }^{1}$ ns, non-significant; ${ }^{*} \mathrm{P}<0.05 ;{ }^{* *} \mathrm{P}<0.01 ;{ }^{* * *} \mathrm{P}<0.001$

of larger countries such as Algeria and Egypt. A number of reasons account for this and the presence of the highest mountains in North Africa (the High Atlas rises to 4,167 m) is one of the most important. Morocco is traversed by four mountain ranges (from north to south, the Riff, Middle Atlas, High Atlas and Anti-Atlas); the two northernmost are refuges for relict species of European origin and all harbour species endemic to the mountains. As a result, ende-

TABLE 5 List of the best GLMs, after 200 replications, of the influence of natural history traits at the levels of species, genus and family (the predictors) on threatened status (the dependent variable). Predictors at the species level are: body size, expressed as mean snout-vent length ( $\mathrm{mm})$ of the largest sex; habitat, number of minor habitats used by the species; output, mean annual reproductive output of the species (number of eggs or newborn). Predictor variables at the genus and family levels are the means of the scores of these variables at the species and genus levels, respectively. Variables with a significant effect are in bold. For more details, see Methods section.

\begin{tabular}{llll}
\hline Variables in the model & df & AIC & P \\
\hline Species & & & \\
$\quad$ Body size, Habitat & 2 & 76.45 & 0.006 \\
$\quad$ Habitat & 1 & 77.07 & 0.006 \\
$\quad$ Body size, Output, Habitat & 3 & 78.34 & 0.016 \\
$\quad$ Output, Habitat & 2 & 78.99 & 0.021 \\
$\quad$ Genus & 2 & 46.43 & 0.026 \\
$\quad$ Mean body size, Mean habitat & 1 & 46.50 & 0.023 \\
$\quad$ Mean habitat & 2 & 47.42 & 0.044 \\
$\quad$ Mean output, Mean habitat & & & \\
$\quad$ Family & 1 & 22.61 & 0.068 \\
$\quad$ Mean habitat & & & \\
\end{tabular}

mism amongst Moroccan reptiles is high for a country embedded in a large continent, and is comparable to that observed on islands. Globally, highlands have been identified as important areas of vertebrate diversity (Rahbek \& Graves, 2001). Other factors that contribute to the high species richness in Morocco are the former connection of north-west Africa with Europe, through what is now the Strait of Gibraltar, the Saharan habitats in the south, and the Macaronesian coastal corridor of the Western Sahara through which some Sahelian species reach the south-west of the country.

The percentage of Moroccan amphibians that are regionally threatened is higher than that of Mediterranean amphibians that are globally threatened (25.5\%; Cox et al., 2006) but approximately the same as the overall percentage of globally threatened amphibians (32.5\%; Stuart et al., 2004). The percentage of Moroccan reptiles that are regionally threatened is similar to that of Mediterranean reptiles that are globally threatened (12.3\%; Cox et al., 2006), suggesting that the overall conservation status of the Moroccan reptile fauna is similar to that observed in the Mediterranean Basin.

Species of the family Scincidae, however, are particularly at risk, and this family includes the only species in Morocco on the brink of extinction. Regionally some amphibian and reptile species are in a category of greater extinction risk, and some reptiles are in a category of lower risk, compared to globally. In regional red list assessments it is usual for some species to fall into a category of higher extinction risk compared to the IUCN Red List (Keller et al., 2005); widely distributed and globally abundant species can be regionally restricted and subject to a demographic sink without the possibility of extra-regional populations to perform a rescue 
effect (Eaton et al., 2005). A lower category of extinction risk at a regional level is less common (IUCN, 2003).

With respect to habitat use, some threatened amphibians occur in desert and savannah. We were unable to measure habitat areas within protected areas because of the lack of accurate maps but according to data in the Executive Program for Protected Areas in Morocco (Ministère de l'Agriculture, 1994) these two habitats are not well represented in the current network of protected areas. Arid habitats in the south of Morocco (scrubland, desert and savannah) are key habitats for threatened amphibians and reptiles and are conservation priorities. These areas have been neglected in demarcation of protected areas, perhaps because of the low biodiversity of endothermic vertebrates or game species there (Milner-Gulland et al., 2006). A good example of such areas are the small dune fields throughout the Taffilat region (i.e. Erg Chebbi), which have a high diversity of reptiles but are threatened by off-road recreational driving and construction of tourism facilities.

Most of the generalist amphibian and reptile species of Morocco are not threatened. A broad pattern of habitat use is considered an important characteristic in determining the ability of species to remain in an area following diverse human impacts (Santos et al., 2007; see Attum et al., 2006, for a particular case). The link between conservation concern and habitat specialization of the herpetofauna of Morocco, however, derives from the fact that many of the threatened species occupy marginal habitats, especially those at the southern or northern limits of their distribution. Conservation of the diversity of the herpetofauna of Morocco requires identification of these marginal habitats, especially in the wet mountain habitats in the north and subtropical Macaronesian scrublands in the south.

The distribution of threatened species can be determined at any scale by an interaction between the biological mechanisms promoting species diversity and the mechanisms (mostly anthropogenic) eroding that diversity (Orme et al., 2005). The major threat to Moroccan amphibians is habitat loss and degradation, and this is also the most pervasive threat to biodiversity generally (Baillie et al., 2004). In Morocco many wetlands have been lost through drainage (Ramdani et al., 2001), with implications for amphibians, which have poor dispersal ability. For reptiles it is the species' intrinsic factors that result in a high percentage being of conservation concern, suggesting that humans have few negative influences on their conservation. The restricted range of some species is the most pervasive threat factor for threatened reptiles, contrary to that observed in the wider Mediterranean Basin (Cox et al., 2006). The number of habitats in which these species occur is probably a surrogate for a variable not included in the model, species' range. This is not the spurious result of analysing a large country without comprehensive data for species' chorology but the consequence of a significant portion of the diversity comprising species at the limit of their ecological requirements and distribution (Gaston, 2003). Morocco, because of its geographical position, contains faunal elements of both the Aethiopic and Palaearctic but some of the species are represented only by scattered and/or small populations. This is the main reason that the number of habitats and restricted range are of overwhelming importance as intrinsic factors threatening many Moroccan reptiles.

Although assignation of a high risk status to species at the edge of their range could be a shortcoming of regional red lists when assessing mobile vertebrates such as birds (Eaton et al., 2005), we believe that this is not the case for reptile populations at the edge of their range because of their lower capacity for dispersal. Unlike amphibians, harvesting, persecution and human disturbance have an impact on reptiles, especially on some of the venomous snake species sought for snake charming and traditional medicine.

We believe this regional red list for Moroccan herpetofauna has more predictive power than the IUCN Red List in priority ranking for national conservation action, providing data for prioritizing habitats and areas for conservation (Rodrigues et al., 2006). Because of its high endemism Morocco makes a disproportionately large contribution to the diversity of the herpetofauna of the Mediterranean Basin. The reptiles of Morocco are also relatively well conserved compared to other Western Mediterranean countries for which this group has been assessed nationally, such as Spain (Pleguezuelos et al., 2002) and Portugal (Cabral, 2005). The regional conservation assessment of Moroccan amphibians and reptiles was different from the assessment of the same species at the global level at the rank of habitats that harbour threatened species and the major threats affecting these species. Although national boundaries are often irrelevant to populations, our national assessment indicates the usefulness of regional red list analyses for detecting conservation priorities in smaller regions (IUCN, 2003). Our results also demonstrate that the current network of protected areas in Morocco does not appear to fulfil the conservation requirements of the country's threatened amphibians and reptiles.

\section{Acknowledgements}

We thank the many people who helped in the field. During the development of this study JCB had a contract from Fundaçao para a Ciência e Tecnologia (Portugal), and GMR was funded for a postdoctoral fellowship by the Spanish government.

\section{References}

Arnold, E.N., Arribas, O. \& Carranza, S. (2007) Systematics of the Palaearctic and oriental lizard tribe Lacertini (Squamata: Lacertidae: Lacertinae) with descriptions of eight new genera. Zootaxa, 1430, 1-86. 
Arntzen, J.W. \& García-Paris, M. (1995) Morphological and allozyme studies of midwife toads (genus Alytes), including the description of two new taxa from Spain. Contributions to Zoology, $65,5-34$.

Ascher, W. \& Healy, R. (1990) Natural Resource Policy-making in Developing Countries. Duke University Press, Durham, USA.

Attum, O., Eason, P., Coвbs, G. \& Baha El Din, S.M. (2006) Response of a desert lizard community to habitat degradation: do ideas about habitat specialists/generalists hold? Biological Conservation, $133,52-62$.

Baillie, J.E.M., Hilton-Taylor, C. \& Stuart, S.N. (eds) (2004) 2004 IUCN Red List of Threatened Species. A Global Species Assessment. IUCN, Gland, Switzerland, and Cambridge, UK.

Barata, M., Harris, D.J. \& Castilho, R. (2008) Comparative phylogeography of north-west African Natrix maura (Serpentes: Colubridae) inferred from mtDNA sequences. African Zoology, 43, $1-7$.

Böнme, W., Schmitz, G. \& Messer, J. (1989) Erster Nachweis der Gattung Telescopus für dier Schlangenfauna Marokkos. Salamandra, 25, 3-76.

Bons, J. \& Geniez, P. (1996) Amphibiens et Reptiles du Maroc. Asociación Herpetológica Española, Barcelona, Spain.

Burnham, K.P. \& Anderson, D.R. (2004) Multimodel inference: understanding AIC and BIC in model selection. Sociological Methods \& Research, 33, 261-304.

Butchart, S.H.M., AkcaKaya, H.R., Kennedy, E. \& HiltonTAYLOR, C. (2006) Biodiversity indicators based on trends in conservation status: strengths of the IUCN Red List Index. Conservation Biology, 20, 579-581.

Cabral, M.J. (2005) Livro Vermelho dos Vertebrados de Portugal. Instituo de Conservacao de Natureza, Lisbon, Portugal.

Caputo, V. \& Mellado, J. (1992) A new species of Chalcides (Reptilia: Scincidae) from north-eastern Morocco. Bolletino Zoologia, 59, 335-342.

Carranza, S. \& Arnold, E.N. (2006) Systematics, biogeography, and evolution of Hemidactylus geckos (Reptilia: Gekkonidae) elucidated using mitochondrial DNA sequences. Molecular Phylogenetics and Evolution, 38, 531-545.

Carranza, S., Arnold, E.N., Geniez, P., Roca, J. \& Mateo, J.A. (2008) Radiation, multiple dispersal and parallelism in the skinks, Chalcides and Sphenops (Squamata: Scincidae), with comments on Scincus and Scincopus and the age of the Sahara Desert. Molecular Phylogenetics and Evolution, 46, 1071-1094.

Carranza, S., Arnold, E.N., Mateo, J.A. \& Geniez, P. (2002) Relationships and evolution of the North African geckos, Geckonia and Tarentola (Reptilia: Gekkonidae), based on mitochondrial and nuclear DNA sequences. Molecular Phylogenetics and Evolution, 23, 244-256.

Carranza, S., Arnold, E.N., Wade, E. \& Fahd, S. (2004) Phylogeography of the false smooth snakes, Macroprotodon (Serpentes, Colubridae): mitochondrial DNA sequences show European populations arrived recently from Northwest Africa. Molecular Phylogenetics and Evolution, 33, 523-532.

Cox, N., Chanson, J. \& Stuart, S. (compilers) (2006) The Status and Distribution of Reptiles and Amphibians of the Mediterranean Basin. IUCN, Gland, Switzerland.

Czech, B. \& Krausman, P.R. (1997) Distribution and causation of species endangerment in the United States. Science, 277, $1116-1117$.

Eaton, M.A., Gregory, R.D., Noble, D.G., Robinson, J.A., Hughes, J., Procter, D. et al. (2005) Regional IUCN red listing: the process as applied to birds in the United Kingdom. Conservation Biology, 19, 1557-1570.
Frost, D.R., Grant, T., Faivovich, J., Bain, R.H., Haas, A., HADDAD, C.F.B. et al. (2006) The amphibian tree of life. Bulletin American Museum of Natural History, 297, 1-370.

GäRDENFORS, U. (2001) Classifying threatened species at national versus global level. Trends in Ecology \& Evolution, 16, 511-516.

Gärdenfors, U., Hilton-Taylor, C., Mace, G.M. \& Rodríguez, J.P. (2001) The application of IUCN Red List Criteria at regional levels. Conservation Biology, 15, 1206-1212.

Gaston, K.J. (2003) The Structure and Dynamics of Geographic Ranges. Oxford University Press, Oxford, UK.

Geniez, P., Mateo, J.A., Geniez, M. \& Pether, J. (2004) The Amphibians and Reptiles of the Western Sahara. Chimaira, Frankfurt and Main, Germany.

GLC (Global Land Cover) (2003) The Global Land Cover for the Year 2000. Http://www-gvm.jrc.it/glc200o/defaultGLC200o.htm [accessed 30 September 2008].

Guicking, D., Joger, U. \& Wink, M. (2008) Molecular phylogeography of the viperine snake Natrix maura (Serpentes: Colubridae): evidence for strong intraspecific differentiation. Organisms Diversity \& Evolution, 8, 130-145.

Hahn, D.E. \& Wallach, V. (1998) Comments on the systematics of Old World Leptotyphlops (Serpentes: Leptotyphlopidae), with description of a new species. Hamadryad, 23, 50-62.

Hoffmann, J.P. (2004) Social and environmental influences of endangered species: a cross-national study. Sociological Perspectives, 47, 79-107.

IUCN (2003) Guidelines for Application of IUCN Criteria at Regional Levels (v. 3.o). IUCN Species Survival Commission, IUCN, Gland, Switzerland.

IUCN (2008) Guidelines for using the IUCN Red List Categories and Criteria (Version 7.0). IUCN, Gland, Switzerland.

IUCN (2010a) The Habitats Authority File and the Threats Type Authority File. Http://www.iucn.org/about/work/programmes/ species/red_list/resources/technical_documents/authority_files/ [accessed 22 May 2010].

IUCN (2010b) The IUCN Red List of Threatened Species. Http:// www.iucnredlist.org/ [accessed 22 May 2010].

Joger, U. (1991) A molecular phylogeny of agamid lizards. Copeia, 1991, 616-622.

Keller, V., Zbinden, N., Schmid, H. \& Volet, B. (2005) A case study in applying the IUCN regional guidelines for national red lists and justifications for their modification. Conservation Biology, 19, 1827-1834.

Lenk, P., Joger, U. \& Wink, M. (2001) Phylogenetic relationships among European ratsnakes of the genus Elaphe Fitzinger based on mitochondrial DNA. Amphibia-Reptilia, 22, 329-339.

Macey, J.R., Jas, I.I., Larson, A., Tuniyev, B.S., Orlov, N. \& PAPENFuss, T.J. (1999) Molecular phylogenetics, tRNA evolution, and historical biogeography in anguid lizards and related taxonomic families. Molecular Phylogenetics and Evolution, 12, $250-272$.

Miller, R.M., Rodríguez, J.P., Aniskowicz-Fowler, T., Bambaradeniya, C., Boles, R., Eaton, M.A. et al. (2007) National threatened species listing based on IUCN criteria and regional guidelines: current status and future perspective. Conservation Biology, 21, 684-696.

Milner-Gulland, E.J., Kreuzberg-Mukhina, E., Grebot, B., Ling, S., Byкоva, E., Aвдusalamov, I. et al. (2006) Application of IUCN red listing criteria at the regional and national levels: a case study from Central Asia. Biodiversity and Conservation, 15, 1873-1886.

Ministère de l’Agriculture (1994) Plan Directeur des Aires protégées. Unpublished Report. Ministère de l'Agriculture, Rabat, Morocco. 
Myers, N., Mittermeier, R.A., Mittermeier, C.C., DA Fonseca, G.A. \& Kent, J. (2000) Biodiversity hotspots for conservation priorities. Nature, 403, 853-858.

Nagy, Z.T., Lawson, R., Joger, U. \& Wink, M. (2004) Molecular systematics of racers, whipsnakes and relatives (Reptilia: Colubridae) using mitochondrial and nuclear markers. Journal of Zoological Systematics and Evolutionary Research, 42, 223-233.

Noss, R.F. (2000) High-risk ecosystems as foci for conservation biodiversity and ecological integrity in ecological risk assessments. Environmental Science Policy, 3, 321-332.

Orme, C.D.L., Davies, R.G., Burgess, M., Eigenbrod, F., Pickup, N., Olson, V.A. et al. (2005) Global hotspots of species richness are not congruent with endemism or threat. Nature, 436, 1016-1019.

Pagel, M. \& Harvey, P.H. (1988) Recent developments in the analysis of comparative data. Quarterly Review of Biology, 63, 413-440.

PEARMAN, P.B. (2001) Conservation value of independently evolving units: sacred cow or testable hypothesis? Conservation Biology, 15, $780-783$.

Pinchera, F. \& Boitani, L. (1997) Application to the terrestrial vertebrates of Italy of a system proposed by IUCN for a new classification of national Red List categories. Biodiversity and Conservation, 6, 959-978.

Pleguezuelos, J.M., Márquez, R. \& Lizana, M. (eds) (2002) Atlas y Libro Rojo de los Anfibios y Reptiles de España. Asociación Herpetológica Española-Ministerio de Medio Ambiente, Madrid, Spain.

Possingham, H.P., Andelman, S.J., Burgman, M.A., Medellin, R.A., Master, L.L. \& Keith, D.A. (2002) Limits to the use of threatened species lists. Trends in Ecology \& Evolution, 17, 503507.

Rahbeк, C. \& Graves, G.R. (2001) Multiscale assessment of patterns of avian species richness. Proceedings of the National Academy of Sciences of the USA, 98, 4534-4539.

Ramdani, M., Flower, R.J., Elkhiati, N., Kraïem, M.M., Fathi, A.A., Birks, H.H. \& PATrick, S.T. (2001) North African wetland lakes: characterization of nine sites included in the CASSARINA Project. Aquatic Ecology, 35, 1386-2588.

Rodrigues, A.S.L. \& Gaston, K.J. (2002) Rarity and conservation planning across geopolitical units. Conservation Biology, 16, 674682.

Rodrigues, A.S.L., Pilgrim, J.D., Lamoreux, J.F., Hoffmann, M. \& Broокs, T.M. (2006) The value of the IUCN Red List for conservation. Trends in Ecology \& Evolution, 21, 71-76.

Rodríguez, J.P., Ashenfelter, G., Rojas-Suárez, F., Garcia Fernández, J.J., SuÁrez, L. \& Dobson, A.P. (2000) Local data are vital to worldwide conservation. Nature, 403, 241.

S A MW A Ys, M.J. (2003) Marginality and national red listing of species. Biodiversity and Conservation, 12, 2523-2525.
Santos, X., Brito, J.C., Pleguezuelos, J.M. \& Llorente, G.A. (2007) Comparing Filippi and Luiselli's 2000 method with a cartographic approach to assess the conservation status of secretive species: the case of the Iberian snake-fauna. AmphibiaReptilia, 28, 17-23.

Schleich, H., Kästle, W. \& Kabish, K. (1996) Amphibians and Reptiles of North Africa. Koelz, Koenigstein, Germany.

Stuart, S.N., Chanson, J.S., Cox, N.A., Young, B.E., RoDrigues, A.S.L., Fischman, D.L. \& W aller, R.W. (2004) Status and trends of amphibian declines and extinction worldwide. Science, 306, 1783-1786.

Trousdale, W. \& Gregory, R. (2004) Property evaluation and biodiversity conservation: decision support for making hard choices. Ecological Economics, 48, 279-291.

Weвв, J.K., Brook, B.W. \& Shine, R. (2002) What make a species vulnerable to extinction? Comparative life-history traits of two sympatric snakes. Ecological Research, 17, 59-67.

Weisrock, D.W., Papenfuss, T.J., Macey, J.R., Litvinvhuk, S.N., Polymeri, R., UGurtas, I.H. et al. (2006) A molecular assessment of phylogenetic relationships and lineage accumulation rates within the family Salamandridae (Amphibia, Caudata). Molecular Phylogenetics and Evolution, 41, 368-383.

Zangari, F., Cimmaruta, R. \& Nascetti, G. (2006) Genetic relationships of the western Mediterranean painted frogs based on allozymes and mitochondrial markers: evolutionary and taxonomic inferences (Amphibia, Anura, Discoglossidae). Biological Journal of the Linnean Society, 87, 515-536.

\section{Appendices}

The appendices for this article are available online at http:// journals.cambridge.org

\section{Biographical sketches}

The authors come from seven research institutions and three countries, including Morocco. During the last 10 years they have collaborated on projects on the ecology, phylogeography and conservation biology of western Mediterranean amphibians and reptiles. The authors have extensive expertise in the distribution and ecology of the herpetofauna of Morocco, having organized and participated in at least 20 scientific expeditions in the country. Some of the authors have participated in red listing analyses at global or regional levels. Collaboratively, the authors seek to investigate the threats to the herpetofauna and improve the conservation of these species in Morocco. 